\title{
PERANCANGAN SISTEM INFORMASI AKUNTANSI PENJUALAN DAN PERSEDIAAN DI CENTRAL STEAK AND COFFEE BOYOLALI
}

\section{DESIGN ACCOUNTING INFORMATION SYSTEM OF SALES AND INVENTORIES AT CENTRAL STEAK AND COFFEE BOYOLALI}

\author{
Dwijanatri Prakasita $N$ \\ Prodi Akuntansi Universitas Negeri Yogyakarta \\ duuii.janatri@gmail.com \\ Mahendra Adhi Nugroho \\ Staf Pengajar Jurusan P. Akuntansi Universitas Negeri Yogyakarta
}

\begin{abstract}
Abstrak: Perancangan Sistem Informasi Akuntansi Penjualan dan Persediaan di Central Steak and Coffee Boyolali
\end{abstract}

Tujuan dari peneltian ini adalah untuk mengetahui sistem informasi akuntansi penjualan dan persediaan yang ada di Central Steak and Coffee dan kemudian merancang sistem informasi akuntansi penjualan dan persediaan yang sesuai untuk Central Steak and Coffee. Penelitian ini adalah penelitian pengembangan. Subjek penelitian ini adalah Central Steak and Coffee, dan objek penelitian ini adalah sistem informasi akuntansi penjualan dan persediaan Central Steak and Coffee. Metode pengumpulan data terdiri dari: wawancara, pengamatan, dan observasi. Metode analisis yang digunakan adalah analisis PIECES, analisis kebutuhan sistem, dan analisis kelayakan sistem TELOS, Software yang dgunakan adalah SQL Server dan Microsoft Vsual Studio. Hasil penelitian ini menunjukkan bahwa: (1) Sistem informasi akuntansi penjualan dan persediaan di Central Steak and Coffee masih menggunakan sistem manual (2) Fungsi yang terkait dalam sistem informasi akuntansi penjualan adalah frontliner, kitchen, bar, kasir, dan akuntansi, sedangkan untuk persediaan adalah fungsi gudang dan akuntansi. (3) Dokumen yang digunakan dalam sistem informasi akuntansi penjualan adalah nota order dan struck penjualan, dan untuk persediaan adalah nota pembelian. (4) Catatan yang digunakan dalam sistem informasi akuntansi penjualan adalah catatan penjualan, sedangkan untuk persediaan adalah kartu stok. (5) Prosedur sistem informasi akuntansi penjualan antara lain pencatatan pesanan, pemrosesan pesanan, penyajian pesanan, penerimaan pembayaran dan pencatatan. Sedangkan untuk persediaan adalah prosedur penjualan dan pembelian (6) Berdasarkan analisis PIECES dapat disimpulkan bahwa sistem lama masih memiliki banyak kelemahan dalam keenam aspek, dan berdasarkan analisis kebutuhan sistem, secara fungsional dan non fungsional, perancangan sistem yang baru diperlukan bagi perusahaan. Berdasarkan hasil analisis kelayakan sistem, sistem ini dinilai layak dari kelima aspek TELOS (7) Pengembangan sistem meliputi: (a) Desain database terdiri dari 9 tabel yang meliputi: Tabel login, user, menu, penjualan, pemasok, pembelian, menu detail dan penyesuaian, (b) desain input yang terdiri dari 9 form yaitu: form login, barang, menu, menu detil, pemasok, pembelian, penjualan, stok awal, dan penyesuaian. (c) Desain output terdiri dari: laporan persediaan, pembelian, dan penjualan (d) Hasil dari implementasi menunjukkan bahwa sistem dapat berjalan dengan lancar dan konversi yang digunakan adalah konversi langsung.

Kata Kunci: Sistem Informasi Akuntansi Penjualan dan Persediaan, Central Steak and Coffee, System Development Life Cycle (SDLC), konversi langsung

\section{Abstract: Design Accounting Information System of Sales and Inventories at Central Steak and Coffee Boyolali}

This purpose of this study is to determine the accounting information system of sales and inventories that available at Central Steak and Coffee and then design the accounting information system of sales and inventories that suitable for Central Steak and Coffee.This study is research and development. The subject of this study is Central Steak and Coffee, and the objects of this study are accounting information system of sales and inventories of Central Steak and Coffee. Data collection methods that used in this study are interview, examination, and observation. The data analysis method that used in this study are: PIECES analysis, needs of system analysis, and feasibility of system analysis TELOS. Software that used in this study are SQL Server and Microsoft Visual Studio. Based on this research, known that (1) accounting information system of sales and inventories in Central Steak and 


\section{JURNAL NOMINAL / VOLUME VII NOMOR 1 / TAHUN 2018}

Coffee is still using manual technique. (2) Function related to accounting information system of sales are frontliner, kitchen, bar, cashier, and accounting, for the inventories the related function are warehouse and accounting. (3) Document related to accounting information system of sales are order note and sales struck, and for inventories is purchase note.(4) Records used in accounting information system of sales is sales record, and for inventories is stock card. (5)Procedure of accounting information system of sales including record the order, processing the order, deliver the order, receive the payment, and recording the sales and for inventories are sales and purchasing procedure. (6) Based on PIECES analysis, the previous system still lack in six aspects, and based on needs of system analysis, functionally and non-functionally, design of new system is needed. Based on feasibility of system analysis, it shown that the system is feasible to be developed. (7) the system development including: (a) database design consist of 9 tables: login, user, menu, sales, supplier, purchasing, detail of menu, and adjustment table (b) input design consist of 9 forms: login, goods, menu, detail of menu, supplier, purchasing, sales, initial stock, and adjustment form. (c) output design consist of: inventory report, purchasing report, and sales report. (d) from result of the implementation, it shown that the system could works properly, and the conversion method that used is direct conversion method.

Keyword: Accounting Information System of Sales and Inventories, Central Steak and Coffee, System Development Life Cycle (SDLC), direct conversion

\section{PENDAHULUAN}

Perkembangan teknologi yang semakin pesat berpengaruh pada banyak aspek, salah satunya adalah aspek ekonomi dan juga bisnis. Persaingan antar usaha menjadi semakin ketat. Semakin berkembangnya suatu usaha, agar dapat bersaing di dalam pasar sebuah usaha dituntut untuk meningkatkan kualitas kerja, mutu pelayanan dan ketepatan data. Selain itu suatu usaha harus memiliki informasi yang akurat, relevan, dan tepat waktu. Untuk mendapatkan informasi yang demikian, dibutuhkan sistem informasi yang baik dan tepat. Karena sistem infomasi yang baik saja tidak cukup, sistem tersebut harus sesuai dengan kebutuhan dan kegiatan bisnis yang dilakukan oleh perusahaan tersebut. Seperti yang kita ketahui, dengan sistem yang baik maka kesalahan yang timbul karena ketidak efisiensi operasi, kurangnya informasi yang memadai, dan kesalahan yang ditimbulkan oleh manusia dapat diminimalisir. Informasi yang akurat dan tepat waktu akan sangat membantu perusahaan dalam hal pengambilan keputusan dan menetukan langkah-langkah yang harus dilakukan untuk mendukung kegiatan operasi dan juga dalam hal mengembangkan perusahaan.

Melihat kebutuhan informasi yang semakin lama meningkat, maka diperlukannya suatu sistem yang baik dan cepat. Suatu sistem dikatakan baik apabila akan memudahkan semua proses, salah satunya dengan jalan komputerisasi pada perusahaan dengan adanya bantuan ini dan Kelebihan-kelebihan yang dimiliki oleh teknologi tersebut yaitu dalam pengolahan data dan penghematan waktu yang digunakan untuk memprosesnya, dibandingkan dengan menggunakan cara lama yaitu secara manual.

Sistem merupakan sekelompok unsur yang erat berhubungan satu dengan yang lainnya, yang berfungsi bersama-sama untuk mencapai tujuan tertentu (Mulyadi, 2001:1). 


\section{JURNAL NOMINAL / VOLUME VII NOMOR 1 / TAHUN 2018}

Sistem yang baik akan mengurangi risiko kesalahan dalam menangani transaksitransaksi yang jumlahnya banyak dan transaksi yang terjadi berulang-ulang. Akuntansi digunakan untuk mencatat transaksi yang berulang-ulang tersebut dan kemudian menghasilkan output berupa laporan keuangan.

Warren dkk (2005:10) menjelaskan bahwa secara umum, akuntansi dapat didefinisikan sebagai sistem informasi yang menghasilkan laporan kepada pihak-pihak yang berkepentingan mengenai aktivitas ekonomi dan kondisi perusahaan.

Romney dan Steinbart (2006 : 3) menyatakan bahwa Sistem informasi akuntansi adalah sistem yang mengumpulkan, mencatat dan memproses data untuk menghasilkan informasi untuk pengambilan keputusan. Kemudian sistem informasi akuntansi menurut Krismiaji (2010 : 4) adalah sebuah sistem yang memproses data dan transaksi guna menghasilkan informasi yang bermanfaat untuk merencanakan, mengendalikan dan mengoperasikan bisnis,

Berdasarkan penjelasan di atas, dapat disimpulkan bahwa untuk menghasilkan output sistem informasi akuntansi yang baik harus mengandung perhitungan perodik antara biaya dan hasil dari kegiatan, dan informasi keuangan perusahaan kepada managemen secara tepat dan akurat, dimana kegiatan tersebut harus dilakukan dengan baik dan efisien sehingga mengurangi risiko kesalahan dalam menghasilkan informasi yang cepat dan akurat yang digunakan sebagai acuhan pengambilan keputusan untuk masa yang akan datang.

Penelitian yang dilakukan Masyitah (2005) pada perusahaan dagang, menyatakan pendapatan terbesar obyek yang diteliti adalah dari penjualan barang dagang dan pengeluaran terbesar adalah berasal dari pembelian barang dagangan. Oleh karena itu, penelitian dilakukan untuk merancang atau mendesain sistem informasi yang baik untuk diterapkan pada perusahaan, baik itu siklus pendapatan dan siklus pengeluaran pada kas.

Sistem informasi akuntansi penjualan merupakan sistem yang berpengaruh besar terhadap keberhasilan suatu perusahaan karena penjualan merupakan kegiatan bisnis yang dilakukan perusahaan untuk dapat memperoleh keuntungan. Penjualan berhubungan langsung dengan persediaan. Menurut Suyadi Prawirosentono (2009) persediaan adalah kekayaan lancar yang terdapat dalam perusahaan dalam bentuk persediaan bahan mentah (bahan baku/raw material), barang setengah jadi (work in proccess), dan barang jadi (finished goods). Menurut Sulistyo Heripracoyo (2009) persediaan adalah aktiva perusahaan yang meliputi barang jadi yang tersedia untuk dijual kembali, barang dalam penyelesaian yang sedang diproduksi dan bahan serta 


\section{JURNAL NOMINAL / VOLUME VII NOMOR 1 / TAHUN 2018}

perlengkapan yang digunakan dalam proses produksi.

Obyek dalam penelitian ini adalah sistem informasi akuntasi penjualan dan persediaan di Central Steak and Coffee. Central Steak and Coffee sendiri adalah sebuah usaha yang bergerak di bidang kuliner. Kegiatan operasi di Central Steak and Coffee dilakukan setiap hari. Dengan sistem operasi yang demikian, manajemen perusahaan memerlukan informasi akuntansi yang cepat dan juga akurat. Sehingga penerapan sistem informasi akuntansi sangat dibutuhkan perusahaan untuk mendapatkan informasi yang baik agar dapat memperlancar aktivitas bisnis perusahaan. Peranan sistem informasi akuntansi sangat besar dalam upaya pelayanan pelanggan. Seluruh siklus akuntansi perusahaan harus dilaksanakan dengan cara yang efisien dan juga efektif, agar tidak terjadi kesalahan dalam pencatatan dan menyebabkan kesalahan pengambilan keputusan dan terjadi fraud dalam perusahaan yang sudah berulang kali terjadi pada perusahaan ini yang disebabkan karena tidak efektif dan jelasnya sistem yang berjalan. Ketidak efektifan pengelolaan suatu informasi dapat mengakibatkan kekacauan dalam pengambilan keputusan, kesulitan pengendalian operasional serta perencanaan teknis dan strategis yang tidak baik menyebabkan terjadi fraud yang dilakukan oleh pegawai.
Persediaan yang dikendalikan dengan baik akan mempengaruhi perkembangan perusahaan. Persediaan yang pengendaliannya kurang akan mengakibatkan kerugian yang besar mengingat usaha Central Steak and Coffee ini merupakan usaha yang bergerak di bidang kuliner, dan persediaan merupakan hal yang penting dalam kegiatan operasi di Central Steak and Coffee.

Terdapat banyak transaksi penjualan dilakukan dalam sehari di Central Steak and Coffee, dan hal itu menyebabkan karyawan tidak dapat mencatat transaksi dengan cepat. Penggunaan komputer yang masih minim karena masih menggunakan sistem manual membuat risiko salah catat menjadi sangat besar. Selain itu teknik pengarsipan yang kurang baik, dokumen penjualan tidak memiliki dokumen rangkap sehingga dokumen mudah hilang karena penyimpanannya kurang baik. Dengan adanya hal seperti itu, maka informasi yang dihasilkan menjadi kurang akurat.

Sistem informasi akuntansi persediaan yang ada di Central Steak and Coffee juga masih menggunakan prosedur manual dimana bagian gudang yang masih merangkap menjadi bagian penerimaan dan pengadaan barang mencatat persediaan dan membuat laporannya secara manual. Selain itu dokumen yang digunakan untuk mencatat pemakaian dan pengadaan barang masih kurang lengkap. Sehingga hal tersebut 


\section{JURNAL NOMINAL / VOLUME VII NOMOR 1 / TAHUN 2018}

menyebabkan ketidak efektifan dalam pengelolaan persediaan, informasi yang dihasilkan juga kurang bisa dihandalkan. Padahal Central Steak and Coffee sebagai usaha yang bergerak dibidang kuliner, sistem informasi akuntansi penjualan dan persediaan adalah hal yang vital dan informasi mengenai penjualan dan persediaan sangat dibutuhkan kecepatan dan kehandalannya. Melihat kebutuhan akan informasi yang cepat, akurat, dan handal, Central Steak and Coffee membutuhkan sistem informasi akuntasi penjualan dan persediaan yang sesuai, karena sistem informasi akuntansi yang sesuai bisa memberikan perusahaan informasi yang cepat, akurat dan handal yang dapat membantu perusahaan dalam kegiatan operasinya dan meningkatkan laba.

Berdasarkan uraian di atas, penulis merasa tertarik untuk merancang dan mendesain sistem infomasi akuntansi penjualan dan persediaan pada perusahaan dan menjadikkannya bahan penelitian dalam bentuk skripsi yang berjudul: Perancangan Sistem Informasi Akuntansi Penjualan dan Persediaan di Central Steak and Coffee Boyolali.

\section{METODE PENELITIAN}

Peneltian ini dilaksanakan di Central Steak and Coffee yang terletak di Jalan Pandanaran No 309, Boyolali.
Pelaksanaan penelitian akan dimulai pada bulan Desember 2014. Jenis penelitian yang akan dilakukan oleh penulis adalah penelitian dan pengembangan. Proses pengembangan yang dilakukan oleh penulis adalah mengembangkan sistem yang sudah ada menjadi sistem penjualan dan persediaan yang berbasis komputer, sehingga dapat mengatasi permasalahan yang ada di proses manual.

Subjek penelitian adalah Central Steak and Coffee. Sedangkan objek penelitian adalah sisten informasi akuntansi penjualan dan persediaan pada Central Steak and Coffee.

Teknik pengumpulan data yang dilakukan dalam penelitian ini adalah observasi, pengamatan, dan wawancara. Metode Pengembangan Sistem yang digunakan untuk analisis sistem adalah analisis PIECES, analisis kebutuhan sistem, dan analisis kelayakan sistem. Tahap desain sistem dbagi menjadi tiga yaitu: Permodelan Database, Permodelan Proses. Dan Desain Interface. Desain Interface sendiri terdiri dari:

1. Desain Database

a. Tabel Login

b. Tabel User

c. Tabel Barang

d. Tabel Menu

e. Tabel Penjualan

f. Tabel pemasok

g. Tabel Pembelian 


\section{JURNAL NOMINAL / VOLUME VII NOMOR 1 / TAHUN 2018}

h. Tabel Menu Detail

i. Tabel Penyesuaian

2. Desain Input

a. Form Login

b. Form Master Barang

c. Form Master Menu

d. Form Master Menu Detail

e. Form Master Pemasok

f. Form Master Pembelian

g. Form Master Penjualan

h. Form Stok Awal

i. Form Penyesuaian

3. Desain output

a. Report Persediaan

b. Report Pembelian

c. Report Penjualan

Konversi yang digunakan dalam penelitian ini adalah metode konversi langsung.

\section{HASIL PENELITIAN}

Sistem Informasi Akuntansi Penjualan dan Persediaan yang Diterapkan pada Central Steak and Coffee

Berdasarkan hasil penelitian ini, dapat dilihat bahwa Central Steak and Coffee masih menggunakan sistem manual dalam operasi perusahaan. Hal itu bisa dilihat dalam sistem informasi akuntansi penjualan dan persediaan yang terjadi di Central Steak and Coffee yang masih minim dalam pemanfaatan teknologi komputer. Sistem informasi akuntansi penjualan dan persediaan yang ada di Central Steak and Coffee masih memiliki kelemahan dalam pemrosesan transaksi penjualan dan persediaan, pelaporan penjualan, pelaporan pembelian, dan pelaporan persediaan barang.. Untuk mengatasi kelemahan tersebut, salah satu cara yang dapat digunakan adalah dengan mengaplikasikan sistem infomasi akuntansi penjualan dan persediaan yang tepat.

Fungsi yang Terkait dengan Sistem Akuntansi Penjualan dan Persediaan pada Central Steak and Coffee

Berdasarkan hasil penelitian yang telah dilakukan, fungsi-fungsi yang terkait dalam sistem infomasi akuntansi penjualan pada Central Steak and Coffee terdiri dari fungsi forntliner, fungsi kitchen, fungsi bar, fungsi kasir, dan fungsi akuntansi. Sedangkan fungsi yang terkait dengan sistem informasi akuntansi persediaan terdiri dari fungsi gudang, dan fungsi akuntansi. Dokumen yang Terkait dengan Sistem Informasi Akuntansi Penjualan dan Persediaan di Central Steak and Coffee

Berdasarkan hasil penelitian yan telah dilakukan, ditunjukkan bahwa dokumen yang terkait dengan sistem informasi akuntansi penjualan yaitu nota order dan struk. Sedangkan untuk sistem informasi persediaan, dokumen yang digunakan adalah nota pembelian.

Catatan Akuntansi yang Terkait dengan Sistem Informasi Akuntansi Penjualan dan Persediaan di Central Steak and Coffee 


\section{JURNAL NOMINAL / VOLUME VII NOMOR 1 / TAHUN 2018}

Berdasarkan hasil penelitian, ditunjukkan bahwa catatan akuntansi yang terkait dengan sistem informasi akuntansi penjualan dan persediaan di Central Steak and Coffee masih sederhana. Catatan yang digunakan dalam sistem informasi akuntansi penjualan dan persediaan di Central Steak and Coffee adalah catatan penjualan dan kartu stok.

Prosedur Sistem Informasi Akuntansi Penjualan dan Persediaan di Central Steak and Coffee

Berdasarkan hasil penelitian, prosedur yang terkait dengan sistem informasi akuntansi penjualan di Central Steak and Coffee adalah proses pencatatan pemesanan, kemudian pemrosesan pesanan, penyajian pesanan, hingga penerimaan pembayaran atas pesanan dan juga pencatatan atas penjualan. Sedangkan prosedur yang terkait dengan sistem informasi akuntansi persediaan di Central Steak and Coffee adalah prosedur penjualan dan pembelian persediaan..

Sistem Pengendalian Intern dalam Sistem Akuntansi Penjualan yang Diterapkan di Central Steak and Coffee

Berdasarkan hasil penelitian, ditunjukkan bahwa pengendalian internl pada sistem akuntansi penjualan dan persediaan di Central Steak and Coffee masih belum baik, hal ini dibuktikan dengan beberapa hal sebagai berikut:

Unsur Organisasi
Struktur organisasi di Central Steak and Coffee sebenarnya sudah baik dan rapi, hanya saja dalam praktiknya pemisahan tugas masih kurang baik. Perusahaan belum memisahkan bagian kasir dan frontliner, karena kadang bagian frontliner merangkap tugas sebagai kasir. Selain itu perusahaan juga belum memisahkan bagian gudang dan bagian pembelian, semua dilakukan oleh satu orang yaitu bagian supervisor. Dengan pemisahan secara tegas dalam suatu struktur ssorganisasi, maka kecurangan dan kesalahpahaman antar pegawai bisa dikurangi.

Unsur Otorisasi dan Prosedur Pencatatan Nota order dibuat hanya dua rangkap, dan kedua lembar nota order tersebut diberikan ke bagian kitchen dan bar, bagian kasir hanya mendapatkan nota order dari dua bagian tersebut. Selain itu, nota oder tidak memiliki nomor urut, sehingga mudah bagi karyawan untuk melakukan kecurangan dengan menghilangkan satu nota atau lebih. Dokumen yang berhubungan dengan persediaan dibuat oleh satu bagian dan hanya dilaporkan setiap akhir bulan. Tidak ada transparasi dalam pencatatan barang yang masuk dan keluar dari bagian pembelian dan gudang

Praktik yang Sehat

Kegiatan penjualan sepenuhnya dilakukan oleh para karyawan saja, supervisor jarang mengecek transaksi yang dilakukan karyawan, melainkan hanya 


\section{JURNAL NOMINAL / VOLUME VII NOMOR 1 / TAHUN 2018}

mengecek proses penjualan yang terjadi. Selain itu manajer hanya menerima nota order dari bagian kasir setiap hari setelah operasi perusahaan selesai, sehingga karyawan dengan mudah dapat melakukan kecurangan. Selain itu transaksi pembelian dan pengelolaan persediaan dikelola oleh supervisor saja. Kartu stok yang digunakan untuk mencatat persediaan disimpan oleh supervisor, dan hanya dilaporkan satu kali dalam satu bulan

Analisis Sistem Informasi Akuntansi Penjualan dan Persediaan pada Central

\section{Steak and Coffee}

Analisis sistem informasi akuntansi penjualan dan persediaan yang dilakukan di Central Steak and Coffee terdiri dari: analisis PIECES, penulis menemukan kelemahan pada sistem yang lama, antara lain sistem yang lama kurang efektif dan efisien dalam pemrosesan transaksi dan pencatatannya.. Selain itu sisrem lama membutuhkan waktu yang cukup untuk membuat laporan yang digunakan perusahaan dalam pengambilan keputusan. Sistem lama juga membutuhkan biaya yang lebih banyak. Kemudian analisis kebutuhan sistem, berdasarkan analisis kebutuhan fungsional dan non fungsional, pengembangan sistem dibutuhkan oleh Central Steak and Coffee.Berdasarkan analisis kelayakan sistem, sistem yang baru secara teknis, operasional, hukum, dan ekonomi, dan sosial dinyatakan layak.
Perancangan Sistem Informasi Akuntansi Penjualan dan Persediaan di Central Steak and Coffee

Dalam perancangan sistem informasi akuntansi penjualan dan persediaan di Central Steak and Coffee, penulis menggunakan tiga permodelan, yaitu: permodelan database, permodelan proses, dan desain interface. Metode perancangan tersebut didasarkan pada hasil pengamatan dan analisis yang telah dilakukan di Central Steak and Coffee.

Implementasi Sistem Informasi Akuntansi Penjualan dan Persediaan di Central Steak and Coffee

Hasil dari implementasi sistem menunjukkan bahwa sistem informasi akuntansi penjualan dan persdiaan dapat berjalan dengan lancar. Sistem informasi akuntansi penjualan dan persediaan membuat penyimpanan data yang berhubungan dengan transaksi penjualan dan pembelian persediaan menjadi semakin mudah. Selain itu menjaga keamanan dan kualitas data agar tidak rusak. Konversi yang dilakukan adalah konversi langsung karena sistem informasi akuntansi yang dikembangkan hanya sistem informasi akuntansi penjualan dan persediaan saja.

Tampilan dari aplikasi yang digunakan ntuk mendukung sistem informasi akuntansi penjualan dan persediaan di Central Steak and Coffee:

Form Login 


\section{JURNAL NOMINAL / VOLUME VII NOMOR 1 / TAHUN 2018}

Form Login merupakan form dimana user memasukkan data berupa username dan password untuk bisa masuk dan mengakses aplikasi.

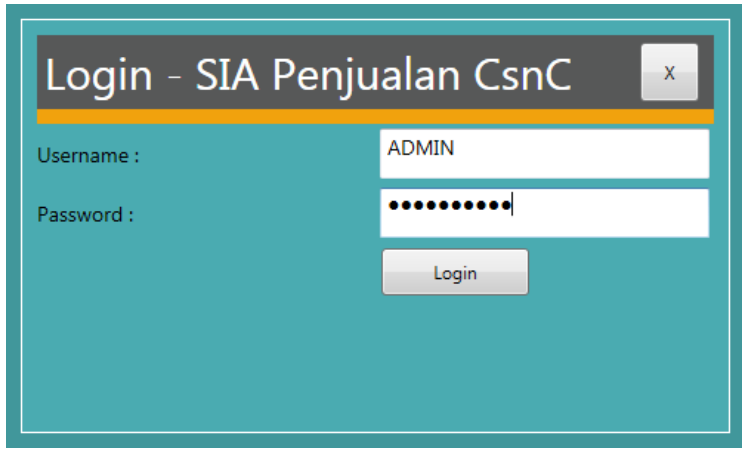

Tampilan Login

Menu Utama

Dalam Home ini terdapat Menu Bar yang berisi menu barang yang berisi data barang, operator yang berisi daftar operator yang bisa membuka aplikasi, pemasok yang berisi data pemasok, kemudian menu penjualan dan pembelian, dan laporan persediaan, pembelian dan laporan penjualan. Kemudian dibawah menu terdapat menu lain, yaitu form menu, form barang, pemasok, stok awal barang, dan form penyesuaian yang berada di dalam form persediaan. Selain itu juga terdapat form transaksi penjualan dan pembelian

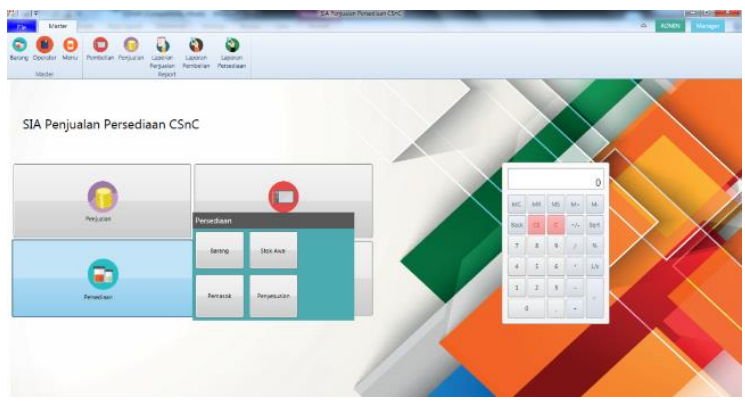

Tampilan Menu Utama
Form Operator

Form Operator adalah form yang berguna untuk mengisi atau input data operator/user yang diperbolehkan membuka aplikasi. Form ini meliputi: Nama operator, kemudian Username, Level untuk membedakan apakah itu kasir, admin, manajer atau supervisor, Password dan Confirm password untuk meyakinkan password yang dimasukkan adalah benar

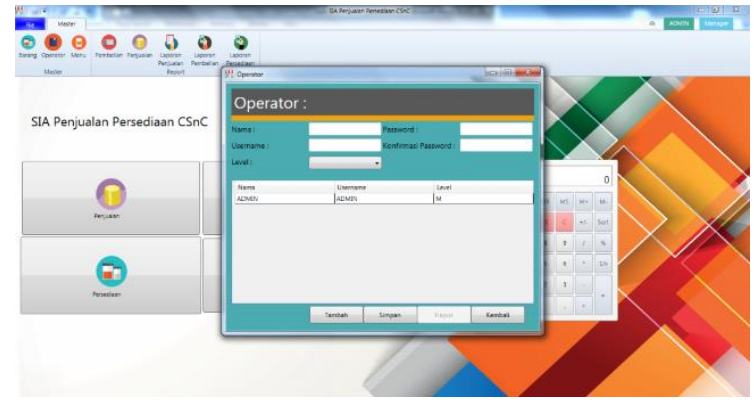

Tampilan Form Operator

Form Menu

Form menu adalah form tempat pengisian produk yang akan dijual. Form ini meliputi Kode menu, Nama menu, dan Harga menu tersebut.

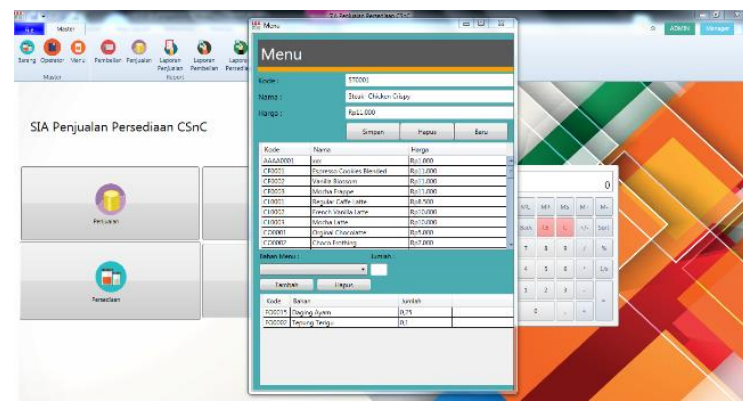

Tampilan Form Menu

Form Menu Detail

Form Menu Detail adalah form tempat mengisikan detail dari produk yang dijual. Form ini berisi Bahan Menu yang berisi daftar barang mentah yang digunakan, 


\section{JURNAL NOMINAL / VOLUME VII NOMOR 1 / TAHUN 2018}

kemudian Jumlah untuk menunjukkan jumlah barang yang digunakan

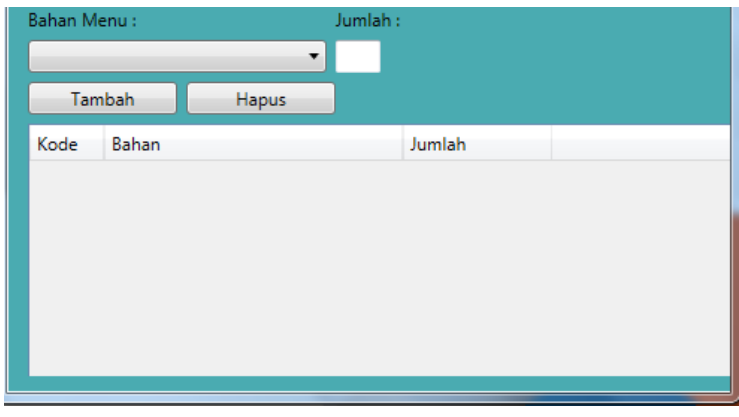

Tampilan Form Menu Detail

Form Barang

Form barang adalah form tempat pengisian atau input data bahan baku yang digunakan dalam sistem persediaan. Form ini meliputi: Kode Barang, Nama Barang, Satuan, Stok Minimal, Harga dan Pemasok tempat dimana barang tersebut dibeli

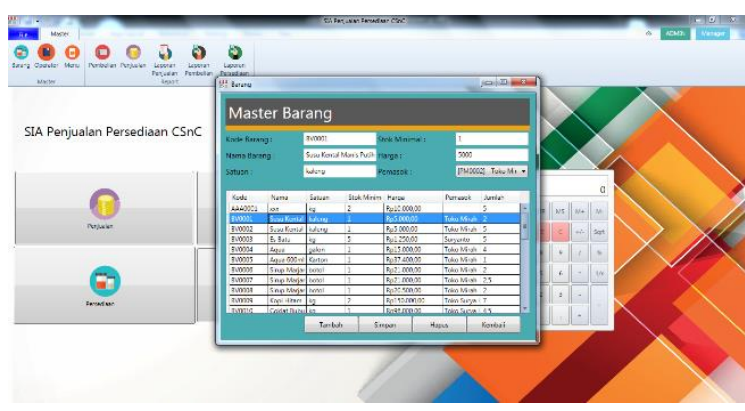

Tampilan Form Barang

Form Pemasok

Form pemasok adalah form tempat pengisian daftar dari pemasok bahan baku yang digunakan dalam sistem persediaan. Dalam form ini terdapat menu untuk memasukkan data pemasok yang meliputi: Kode Pemasok, Nama Pemasok, Alamat, dan Nomor Telefon pemasok.

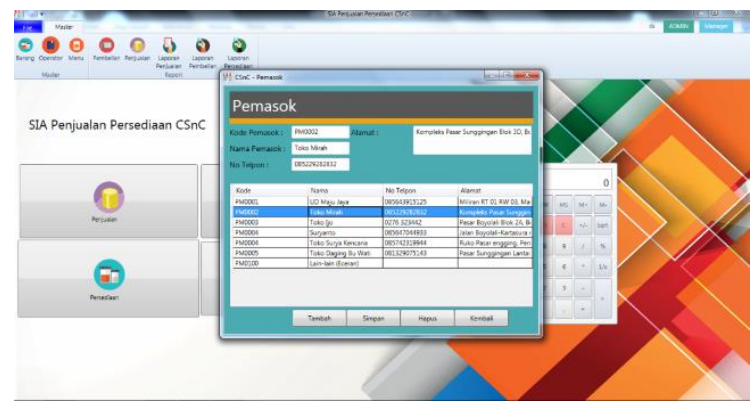

Tampilan Form Pemasok

Form Stok Awal

Form stok awal adalah form yang digunakan untuk mengisi stok awal barang. Stok awal barang hanya diisi pertama kali sebelum terjadi transaksi pembelian atau penjualan. Form ini meliputi: Tanggal untuk menentukan tangga berapa stok tersebut dimasukkan, Kode Barang untuk memilih barang yang akan dimasukkan stoknya, Nama Barang (terisi otomatis), Satuan (terisi otomatis), Pemasok (terisi otomatis), dan Jumlah untuk mengisi jumlah stok awal barang.

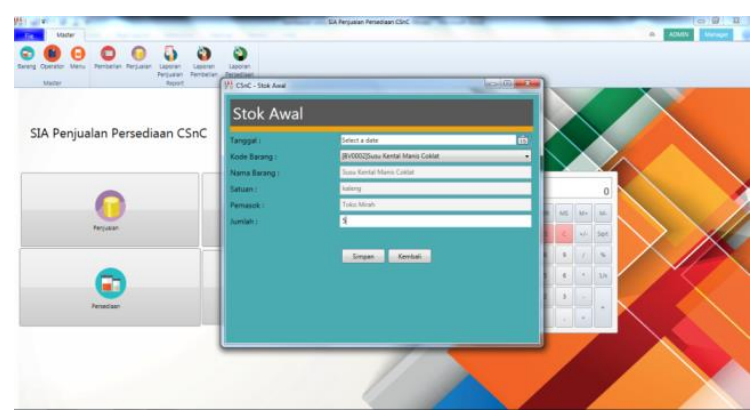

Tampilan Form Stok Awal

Form Penyesuaian

Form penyesuaian adalah form yang digunakan untuk mengisi penyesuaian persediaan. Form ini hanya bisa dibuka oleh manajer 


\section{JURNAL NOMINAL / VOLUME VII NOMOR 1 / TAHUN 2018}

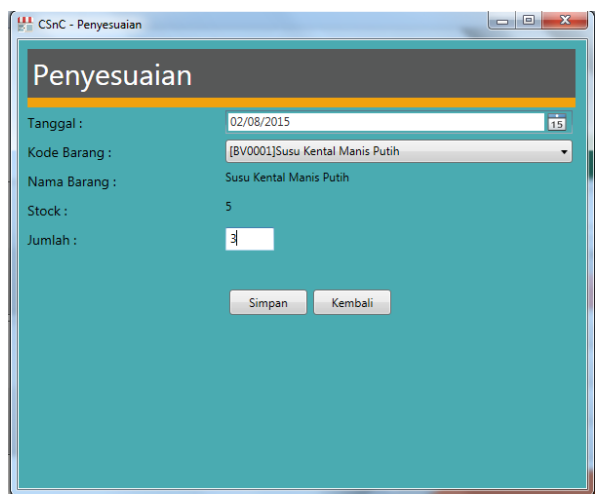

Tampilan Form Penyesuaian

Form Pembelian

Form pembelian adalah form yang digunakan untuk pengisian transaksi pembelian barang atau nota pembelian barang. Pada saat proses pembelian, maka jumlah stok barng yang dibeli secara otomatis akan bertambah. Form ini meliputi Barang untuk memilih barang yang dibeli, kemudian Jumlah untuk menunjukkan berapa jumlah barang yang dibeli dan Tanggal untuk menunjukkan tanggal pembelian barang

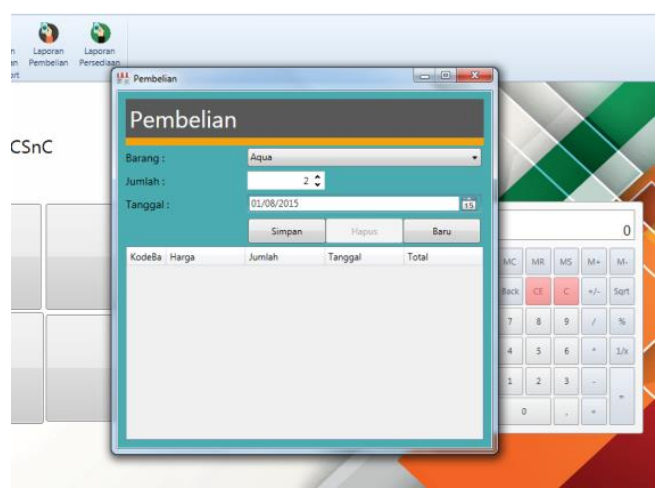

Tampilan form Pembelian

Form Penjualan

Form penjualan adalah form yang digunakan untuk pengisian transaksi penjualan barang dari pelanggan. Pada saat proses penjualan, maka jumlah stok barang akan berkurang sesuai dengan jumlah yang digunakan untuk transaksi penjualan. Form

ini meliputi Menu untuk memilih menu yang dipesan, Harga yang menunjukkan harga menu yang dipesan (terisi secara otomatis), dan Jumlah untuk menunjukkan jumlah yang dipesan. Kemudian dibawahnya terdapat Tanggal untuk mencatat tanggal transaksi, kemudian Nomor Meja untuk mengetahui nomor meja pelanggan, Bayar untuk mengetahui berapa jumlah uang yang dibayarkan pelanggan, selanjutnya adalah Total untuk mengetahui berapa jumlah uang yang harus dibayar pelanggan, dan Kembali menunjukkan berapa uang yang harus dikembalikan ke pelanggan, dan terakhir adalah Print untuk mencetak struk penjualan

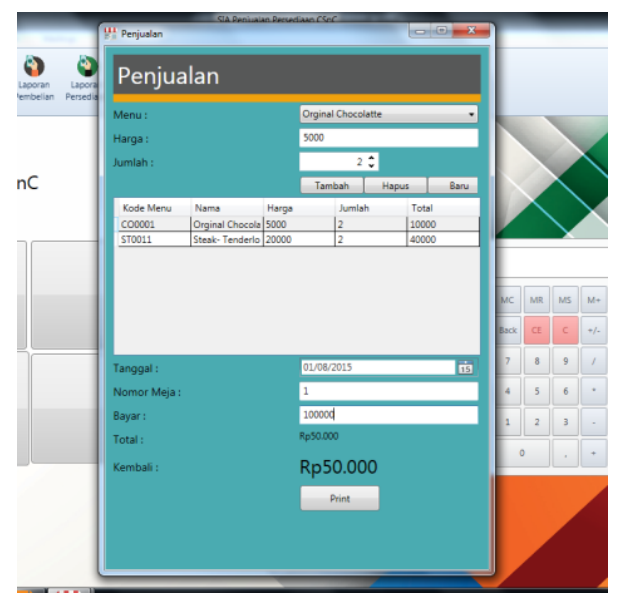

Tampilan form Penjualan

\section{Laporan Persediaan}

Laporan persediaan adalah laporan yang digunaka untuk melihat keseluruhan bahan baku yang ada dalam persediaan beserta jumlah yang tersedia. Dalam form ini terdapat menu tanggal (dari dan sampai) untuk mem-filter data. Jika user ingin melihat data penjualan dari tanggal yang spesifik, user bisa memasukkan tanggal yang diinginkan. Dalam form ini juga 


\section{JURNAL NOMINAL / VOLUME VII NOMOR 1 / TAHUN 2018}

terdapat Barang Masuk dan Barang Keluar untuk memperlihatkan berapa jumlah barang yang dibeli dan barang yang digunakan

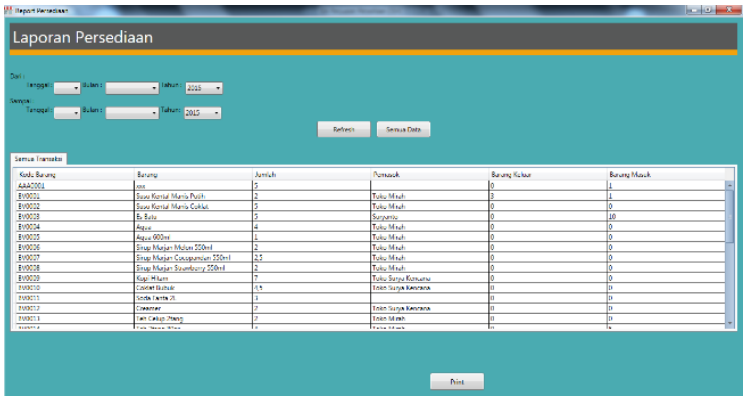

Tampilan Laporan Persediaan

1. Laporan Penjualan

Laporan penjualan adalah laporan yang digunakan untuk melihat daftar atau laporan atas transaksi penjualan yang telah dilakukan. Dalam form ini terdapat menu tanggal (dari dan sampai) untuk mem-filter data penjualan. Jika user ingin melihat data penjualan dari tanggal yang spesifik, user bisa memasukkan tanggal yang diinginkan. Laporan juga tersedia dalam laporan penjualan harian, bulanan, dan tahunan

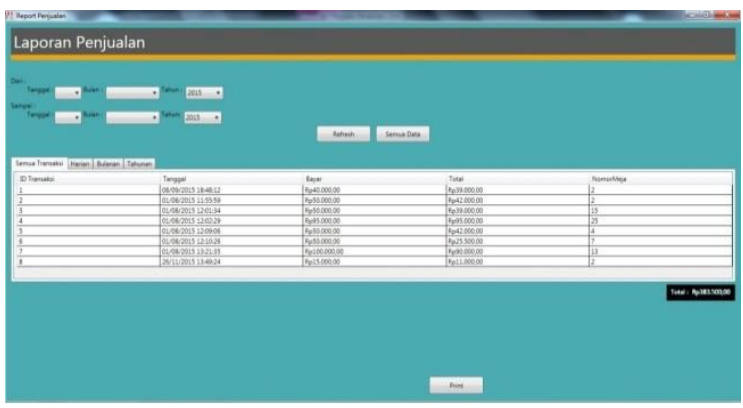

Tampilan Laporan Penjualan

2. Laporan Pembelian

Pembelian adaah laporan yang digunakan untuk melihat daftar atau laporan transaksi pembelian yang telah dilakukan. Dalam form ini terdapat menu tanggal (dari dan sampai) untuk mem-filter data pembelian. Jika user ingin melihat data pembelian dari tanggal yang spesifik, user bisa memasukkan tanggal yang diinginkan. Laporan juga tersedia dalam laporan pembelian harian, bulanan, dan tahunan

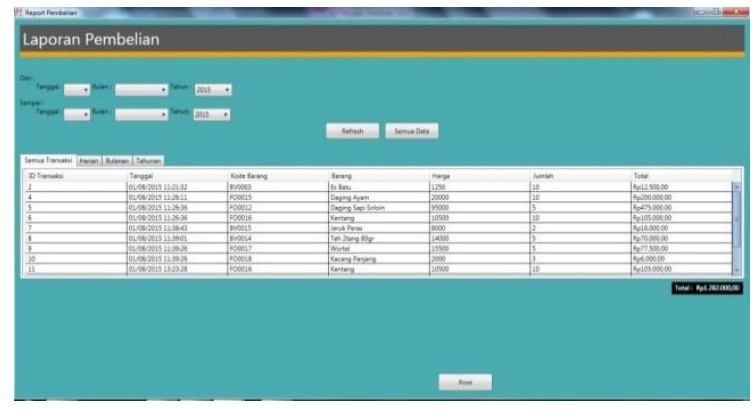

Tampilan Laporan Pembelian

\section{SIMPULAN DAN SARAN}

\section{Kesimpulan}

Hasil penelitian ini menunjukkan bahwa: Fungsi yang terkait dalam sistem informasi akuntansi penjualan adalah frontliner, kitchen, bar, kasir, dan akuntansi, sedangkan untuk persediaan adalah fungsi gudang dan akuntansi. Dokumen yang digunakan dalam sistem informasi akuntansi penjualan adalah nota order dan struck penjualan, dan untuk persediaan adalah nota pembelian. Catatan yang digunakan dalam sistem informasi akuntansi penjualan adalah catatan penjualan, sedangkan untuk persediaan adalah kartu stok. Prosedur sistem informasi akuntansi penjualan antara lain pencatatan pesanan, pemrosesan pesanan, penyajian pesanan, penerimaan pembayaran dan pencatatan. Sedangkan untuk persediaan adalah prosedur penjualan dan pembelian. Berdasarkan analisis PIECES dapat disimpulkan bahwa sistem lama masih memiliki banyak kelemahan 


\section{JURNAL NOMINAL / VOLUME VII NOMOR 1 / TAHUN 2018}

dalam keenam aspek, dan berdasarkan analisis kebutuhan sistem, secara fungsional dan non fungsional, perancangan sistem yang baru diperlukan bagi perusahaan. Berdasarkan hasil analisis kelayakan sistem, sistem ini dinilai layak dari kelima aspek TELOS.

Pengembangan sistem meliputi: Desain database terdiri dari 9 tabel yang meliputi: Tabel login, user, menu, penjualan, pemasok, pembelian, menu detail dan penyesuaian; desain input yang terdiri dari 9 form yaitu: form login, barang, menu, menu detil, pemasok, pembelian, penjualan, stok awal, dan penyesuaian. Desain output terdiri dari: laporan persediaan, pembelian, dan penjualan.

Hasil dari implementasi menunjukkan bahwa sistem dapat berjalan dengan lancar dan konversi yang digunakan adalah konversi langsung.

\section{Saran}

Bagi peneliti selanjutnya diharapkan di masa depan akan ada pengembangan sistem yang lebih baik lagi. Kemudian Di masa depan akan ada perancangan sistem informasi akuntansi yang lebih menyeluruh.

\section{DAFTAR PUSTAKA}

Krismiaji (2010). Sistem Informasi Akuntansi. Yogyakarta : Akademi Manajemen Perusahaan YKPN

Suyadi Prawirosentono. 2009. Manajemen Operasi (Operation Management) Analisi dan Studi. Jakarta: Bumi Aksara
Warren, Carl. S, Reeve, Philip E. Fess (2005). Pengantar Akuntansi. Edisi 21. Jakarta: Salemba empat

Romney, Marshal B., Dan Steinbert, Paul John. (2006). Sistem Informasi Akuntansi. (Alih Bahasa: Deny Arnos Kwary Dan Dewi Fitriasari). Jakarta: Salemba Empat

Sulistyo Heripracoyo. 2009. Analisis dan perancangan sistem informasi akuntansi pembelian persediaan pada PT. Oliser Indonesia. Seminar Nasional Aplikasi Teknologi Informasi 2009 (SNATI 2009). Juni. P. B-93 - B-100 